\title{
Blood urea nitrogen (BUN)
}

National Diabetes Information Clearinghouse (NDIC)

\section{Definitions}

Protein

Defined by National Diabetes Information Clearinghouse (NDIC)

Kidney

Defined by National Diabetes Information Clearinghouse (NDIC)

Urea

Defined by National Diabetes Information Clearinghouse (NDIC)

\section{Source}

National Diabetes Information Clearinghouse (U.S.). (2009). The diabetes dictionary. [Bethesda, Md.]: U.S. Dept. of Health and Human Services, National Institutes of Health, National Institute of Diabetes and Digestive and Kidney Diseases, National Diabetes Information Clearinghouse.

A waste product in the blood that comes from the breakdown of protein. The kidneys filter blood to remove urea. As kidney function decreases, the BUN level increases. 